\title{
Self-Efficacy, Adversity Quotient, and Students' Achievement in Mathematics
}

\author{
Bambang Suryadi ${ }^{1} \&$ Teguh Iman Santoso ${ }^{1}$ \\ ${ }^{1}$ Faculty of Psychology, Universitas Islam Negeri (UIN) Syarif Hidayatullah, Jakarta, Indonesia \\ Correspondence: Bambang Suryadi, Faculty of Psychology, Universits Islam Negeri (UIN) Syarif Hidayatullah, \\ Jakarta, Indonesia. Tel: 62-21-743-3060. E-mail: bambang.suryadi@uinjkt.ac.id
}

Received: March 14, 2017

doi:10.5539/ies.v10n10p12

\author{
Accepted: May 10, $2017 \quad$ Online Published: September 28, 2017 \\ URL: https://doi.org/10.5539/ies.v10n10p12
}

\begin{abstract}
Indonesian students' achievement in mathematics is generally still low compared with other countries. Many psychological factors, both internal and external, influence this poor performance. This study aimed to measure the effect of self-efficacy and the adversity quotient of Grade IX students regarding achievement in mathematics. Both of these internal variables have been selected because students' success in mathematics is determined more by internal factors than by external factors. A survey method was used. The sample included 140 students and was drawn using a probability sampling technique. A self-efficacy scale and an adversity quotient scale were used to collect the data. Students' mathematics achievement was determined based on school test results. The data were analyzed using multiple regressions. The findings reveal significant effects of self-efficacy and the adversity quotient but no significant effects of gender on students' academic mathematics achievement. Therefore, an implication of the study is that we must investigate how to improve students' self-efficacy and adversity quotient in mathematics. The results may be of interest to other developing countries, especially those in Southeast Asia that share similar concerns with Indonesia regarding students' mathematics achievement.
\end{abstract}

Keywords: adversity quotient, endurance, mathematics achievement, self-efficacy, self-concept

\section{Introduction}

\subsection{Introduce the Problem}

Mathematics is a critical subject that must be taught at all levels of education, from primary to secondary. Mathematics is considered one of the most challenging subjects in both primary and secondary school as students often perform poorly in it (Hamid, Shahrill, Matzin, Mahalle, \& Mundia, 2013). Mathematics enhances students' ability to think logically, rationally, critically, accurately, effectively, and efficiently. Thus, if students' achievement in mathematics is low, their ability to think logically, rationally, critically, thoroughly, effectively, and efficiently will also be low. A lack of these skills will impact the nation's ability to develop economically. However, national examination results in 2015 and 2016 showed that the achievement of junior high school students in mathematics was low and decreasing; their scores were 56.28 in 2015 and 50.24 in 2016 (Puspendik, 2016). These scores were lower than the other three subjects tested on the national examination, namely Bahasa Indonesia (70.75), English (57.17), and the Natural Sciences (56.27).

The results of the 2012 PISA survey indicated that Indonesia's score of 375 for Mathematics ranked $64^{\text {th }}$ among the 65 Organization for Economic Cooperation and Development (OECD) member countries. This ranking is far below Vietnam, which placed $17^{\text {th }}$ with a score of 511 (PISA 2013). Similarly, in 2015, Indonesia ranked $65^{\text {th }}$ out of the 72 OECD member countries, while Vietnam ranked $22^{\text {nd }}$ with a score of 495 , and Malaysia was $44^{\text {th }}$ with a score of 446 (PISA, 2016). Clearly, Indonesian students' competence in mathematics has been poor for years. A natural question then arises: what factors lead to our students' poor academic achievement in mathematics? We cannot give accurate and valid answers to this question unless we conduct a study.

Thus, this study aimed to measure the psychological factors that affect students' mathematics achievement. The survey was administered to Grade IX students at Pembangun Lower Secondary Islamic School (MTs Pembangunan), State Islamic University Jakarta (hereafter MTs Pembangunan UIN Jakarta). This study discovered that self-efficacy and the adversity quotient significantly affected students' mathematics achievement. 


\subsection{Explore Importance of the Problem}

The present study aimed to answer the following research questions:

a) Is there a significant effect of self-efficacy and the adversity quotient on students' mathematics achievement?

b) Is there a significant effect of each aspect of self-efficacy (self-confidence in one's ability, socialization ability and positive attitude) and aspects of the adversity quotient (control, origin and ownership, reach, and endurance) on students' mathematics achievement?

c) Is there a significant gender difference related to the effect of self-efficacy and adversity quotient on students' mathematics achievement?

This study has both theoretical and practical consequences. The theoretical benefits will contribute to the field of psychology, particularly educational psychology. People in this field can include this material in educational classes. Regarding practical benefits, administrators, counselors, and teachers can use the findings of this study to reconstruct their lesson plans and give teachers advice about the classroom climate. This information is also important for the broader public as a reference for those who want to examine the issues related to self-efficacy, the adversity quotient and learning achievement.

\subsection{Describe Relevant Scholarship}

Based on the results of a literature review, it can be concluded that many factors, internal and external, affect students' achievement in mathematics. The internal factors include achievement motivation and self-concept (Awan \& Noureen, 2012; Kupari \& Nissinen, 2013), self-directed learning readiness and academic self-efficacy (Saeid \& Eslaminejad, 2017; Kitsantas, Cheema, \& Ware, 2011), self-efficacy (Apollo, 2005 and Shofiah 2002), and students' attitudes towards mathematics learning (Ismail \& Awang, 2009). Natural intellectual ability is another internal factor that affects mathematics achievement (Ghufron \& Risnawati, 2010; Retnaningsih, 1998; and Suri, 2000), but it is far from the only factor. Some research also suggests that the success and failure of students in school are determined by the adversity quotient. Stoltz (2000) states that the adversity quotient is a person's ability to withstand and overcome adversity and difficulties and to able to exceed expectations for their performance and potential. The adversity quotient is composed of four dimensions, namely control, origin and ownership, reach, and endurance (Stoltz, 2000).

Among the internal factors, self-efficacy is considered the most important (Apollo, 2005; Shofiah, 2002). A study by Pawan Kumar Singh and R. P. Shukla (2015) used the social education theory of Bandura (1977) to define self-efficacy. The term denotes self-confidence in successfully organizing and executing tasks, which determines an individual's capacity to control the motives, recognition, and direction of his/her actions. Self-efficacy is enhanced by the support of teachers and parents, specifically in childhood and during adolescence, and it is indirectly influenced by the individual's level of self-respect.

The external factors, on the other hand, consist of socioeconomic status (Hernandez, 2014), teaching strategies and methods (Douglas \& Cebulla, 2000), peer teaching strategy (Abdelkarim \& Abuiyada, 2016), feedback and remediation (James \& Folorunso, 2012), and the characteristics of teachers, schools, educational aids and resources (Ismail \& Awang, 2009). In addition, gender is considered an important factor for students' achievement in mathematics, as indicated in a study by Awan, Noureen, and Naz (2012) in Malaysia and a study by Else-Quest, Hyde, \& Linn (2010) in the United States.

Despite the various studies on the factors affecting mathematics achievement in recent years, a number of important issues remain to be solved. First and foremost, the findings are often inconclusive. In this context, it is argued that there is no single factor that affects students' achievement in mathematics. Second, the findings are limited in terms of generalizability because most studies have been performed in foreign countries with different norms, cultures, traditions, and situations. The question then arises: do similar findings exist in Indonesia, where cultural and societal norms and expectations differ?

\subsection{State Hypotheses and their Correspondence to Research Design}

This study has two hypotheses. The first hypothesis examined whether there was a significant effect of self-efficacy and the adversity quotient on the mathematics achievement of Grade IX students at MTs Pembangunan UIN Jakarta. The second hypothesis examined whether each aspect of self-efficacy (self-confidence in one's ability, socialization ability and positive attitude) and each aspect of the adversity quotient (control, origin and ownership, reach, and endurance) had a significant effect on students' mathematics achievement. 


\section{Method}

\subsection{Identify Subsections}

This study applied a descriptive survey design, which is a non-experimental design used to explain a cause-effect connection. This design was selected because this study's goal is to observe the influence of self-efficacy and the adversity quotient on mathematics achievement and then to use those results to predict the contribution of each independent variable to the dependent variable. A descriptive survey was chosen for economic reasons so that researchers can make use of a representative sample from a large population that would have been infeasible to study.

\subsection{Participants' (Subjects') Characteristics}

The subjects of the research were the Grade IX students at MTs Pembangunan UIN Jakarta for the academic year 2013/2014. Out of 221 students, 140 students were randomly selected to form the sample of the study. The sample consisted of 59 (42.1\%) boys and $81(57.9 \%)$ girls, aged 14 years.

\subsection{Sampling Procedures}

The sample of this study was determined by the probability sampling technique, using a table of random numbers. Once the sample size was determined, the researchers administered the survey to the subjects after obtaining written permission from the Principal of MTs Pembangunan UIN Jakarta. In administering the survey, the researchers were assisted by the subjects' teachers. To avoid interfering with the learning process, the survey was administered ten minutes before class ended. Before distributing the survey to the subjects, the researchers explained the purpose of the research and how to fill out the instrument. The researchers asked the subjects to fill out the instrument completely and objectively, without being influenced by friends or other factors. The researchers also confirmed that all information provided by the subjects would only be used for research purposes and would not affect their grades. This explanation was delivered orally and was written in the introduction of the survey.

\subsection{Data Collection Tools}

The research instruments used for data collection were a self-efficacy scale and an adversity quotient scale in the form of a Likert scale. The former was adapted from Guilford's theory (Apollo, 2005); it measured self-confidence in one's ability, socialization ability and tranquility of attitude. The latter was adapted from the work of Stoltz (2000), and it consists of four dimensions, namely control, origin and ownership, reach and endurance. The data on students' achievement in mathematics were gathered from the school's test results in semester I. The reason for using the school's test results is that they adequately described students' academic performance for one semester.

The self-efficacy scale had 42 items, and its internal reliability was 0.893 . The adversity quotient scale had 39 items, and its internal reliability was 0.891 . Each scale had four answer choices, namely Strongly Disagree, Disagree, Agree and Strongly Agree. In this study, the researchers deliberately eliminated the third choices (neutral option) to avoid the tendency of subjects to fill in the neutral choice.

The original scales were written in English, so they were translated into Indonesian by an English teacher at MTs Pembangunan UIN Jakarta. The translation was then analyzed by Indonesian teachers from the same school to ensure that there were no problems with understanding the questions. In the next step, the researchers reviewed the revised scale and administered it to ten students in Grade IX at MTs Pembangunan UIN Jakarta who were not selected as subjects for this study. The purpose of this pilot test was to determine how long it took to fill in the scale and to make sure no statements on the scale had a dual interpretation or were hard to understand. The students of the pilot study did not ask questions about the instrument and spent about 15 to 20 minutes filling in the two scales.

The data were analyzed using multiple regression analysis while the construct validity testing was performed using Confirmatory Factor Analysis (CFA) with the help of LISREL software version 8.7.

\section{Results}

The data were analyzed with multiple regression analysis, variance analysis and a t-test. The analysis was performed in accordance with the research questions stated in the introduction part of this study. The following sections show the results of the hypothesis testing.

\subsection{The Effect of Self-Efficacy and the Adversity Quotient on Students' Mathematics Achievement}

The results showed revealed a significant effect of self-efficacy and the adversity quotient on students' 
mathematics achievement. The results of the analysis of variance for the effect of self-efficacy and the adversity quotient on students' mathematics achievement are presented in Table 1.

Table 1. Analysis of variance for the effect of self-efficacy and the adversity quotient on students' mathematics achievement

\begin{tabular}{cccccc}
\hline Model & Sum of Squares & Df & Mean Square & F & Sig. \\
\hline Regression & 1992.740 & 2 & 996.370 & & \\
Residual & 13313.431 & 137 & 97.178 & 10.253 & .000 \\
Total & 15306.171 & 139 & & & \\
\hline
\end{tabular}

a. Predictors: (Constant), Adversity Quotient, Self-efficacy

b. Dependent Variable: Academic Achievement in Mathematics

Table 1 shows that the significance value is $0.000(\mathrm{p}<0.05)$; this means that the major hypothesis, which stated that there is a significant effect of self-efficacy and the adversity quotient on students' mathematics achievement, was accepted. Thus, it is understood that self-efficacy and the adversity quotient significantly affected the students' achievement in mathematics. The data in Table 1 also indicate that the $F$ value is 10.253 . The value of the DF table is with 2 degrees of freedom, and 137 were found at 3.06. Therefore, because the F value is greater than the $\mathrm{F}$ table, it can be concluded that the regression equation for this study can be applied.

The results regarding the overall contribution of independent variable (self-efficacy and adversity quotient) to the dependent variable (students' mathematics achievement) are shown in Table 2.

Table 2. The overall contribution of the independent variable (self-efficacy and adversity quotient) to the dependent variable (students' mathematics achievement)

\begin{tabular}{|c|c|c|c|c|c|c|c|c|c|}
\hline \multirow[b]{2}{*}{ Model } & \multirow[b]{2}{*}{$\mathrm{R}$} & \multirow[b]{2}{*}{ R Square } & \multirow[b]{2}{*}{$\begin{array}{l}\text { Adjusted R } \\
\text { Square }\end{array}$} & \multirow[b]{2}{*}{$\begin{array}{l}\text { Std. Error of the } \\
\text { estimate }\end{array}$} & \multicolumn{5}{|c|}{ Change Statistics } \\
\hline & & & & & $\begin{array}{l}\text { R Square } \\
\text { Change }\end{array}$ & F Change & $\mathrm{df} 1$ & $\mathrm{df} 2$ & $\begin{array}{l}\text { Sig. F } \\
\text { Change }\end{array}$ \\
\hline 1 & $.361^{\mathrm{a}}$ & .130 & .117 & 9.85791 & .130 & 10.253 & 2 & 137 & .000 \\
\hline
\end{tabular}

a. Predictors: (Constant), Adversity Quotient, Self-efficacy

Table 2 indicates that the R square (R2) coefficient is 0.130 , which means that $13 \%$ of the variance in students' achievement in mathematics in this study is determined by the variable of self-efficacy and the adversity quotient This means that about $87 \%$ of students' achievement in mathematics is determined by other factors not explored in this study. These factors might include self-regulated learning, achievement motivation, school environment, classroom climate, and parenting styles.

\subsection{The Contribution of Each Dimension of the Independent Variable to Students' Mathematics Achievement}

In this section, the researchers examined whether there is a significant effect of each aspect of self-efficacy (self-confidence in one's ability, socialization ability and positive attitude) and aspects of the adversity quotient (control, origin and ownership, reach, and endurance) on the mathematics achievement of students. The significance of the coefficient regression of each independent variable is presented in Table 3.

Table 3. Coefficient regression of each independent variable

\begin{tabular}{cccccc}
\hline \multirow{2}{*}{ Model } & \multicolumn{2}{c}{ Unstandardized Coefficients } & $\begin{array}{c}\text { Standardized } \\
\text { Coefficients }\end{array}$ & \multirow{2}{*}{ S } & Sig. \\
\cline { 2 - 5 } & $\mathrm{B}$ & Std. Error & Beta & & \\
\hline (Constant) & 55.484 & 4.760 & & 11.657 & .000 \\
Self-efficacy & .194 & .104 & .185 & 1.872 & .063 \\
Adversity quotient & .230 & .104 & .219 & 2.217 & .028 \\
\hline
\end{tabular}

a. Dependent variable: Students' achievement in mathematics 
Table 3 above shows the regression coefficient of each independent variable and its significance. If the significance value is $<0.05$, it can be concluded that the independent variable in this study has a significant effect on the dependent variable. Given this fact, the researchers then determine that the regression equation of students' mathematics achievement is equal to $55,484+0,194 *$ self-efficacy $+0,230 *$ adversity quotient.

Based on the analysis of each dimension of self-efficacy and the adversity quotient, the regression coefficient is summarized in Table 4.

Table 4. Regression coefficient of each dimension of independent variable

\begin{tabular}{rlc}
\hline \multicolumn{2}{c}{ Variable } & Regression Coefficient \\
\hline Self-efficacy & 0.049 (Sig) \\
\hline a. & Self-confidence in one's ability & 0.847 (Non. Sig) \\
b. $\quad$ Socialization ability & 0.080 (Non. Sig) \\
c. $\quad$ Positive attitude & 0.038 (Sig) \\
\hline Adversity Quotient & 0.016 (Sig.) \\
d. $\quad$ Control & 0.256 (Non. Sig) \\
a. $\quad$ Origin and ownership & 0.089 (Non. Sig) \\
b. $\quad$ Reach & \\
c. & Endurance
\end{tabular}

Table 4 reveals that three dimensions of independent variables that significantly affected the students' achievement in mathematics. These three dimensions include self-confidence in one's ability $(\mathrm{p}=0.049<0.05)$, control $(p=0.038<0.05)$, and origin and ownership $(p=0.016<0.05)$. The other four dimensions were not significant; these dimensions were socialization ability, tranquility of attitude, reach, and endurance. The results of the analysis of variance (R2) showed that self-confidence in one's ability contributed $10 \%$, control contributed $2.1 \%$, and origin and ownership contributed $3.2 \%$ to students' achievement in mathematics.

\subsection{The Gender Difference in Students' Mathematics Achievement}

In this study, the researcher further analyzed the students' differences in mathematics achievement based on gender. The results of the analysis are presented in Table 5.

Table 5. Student's differences in mathematics achievement based on gender

\begin{tabular}{ccccccccccc}
\hline Model & $\mathrm{R}$ & $\begin{array}{c}\mathrm{R} \\
\text { Square }\end{array}$ & $\begin{array}{c}\text { Adjusted } \mathrm{R} \\
\text { Square }\end{array}$ & $\begin{array}{c}\text { Std. Error of the } \\
\text { Estimate }\end{array}$ & & \multicolumn{3}{c}{ Change Statistics } \\
\hline & & & & & & & R Square \\
Change & Change & df1 & df2 & Sig. F \\
Change
\end{tabular}

a. Predictors: (Constant), Gender

Table 5 shows that the value of $\mathrm{R}$ square obtained from the analysis are 0.002 . This means that gender contributed only about $0.2 \%$ to students' mathematics achievement, and there were no significant differences between boys and girls in their mathematics achievement, as $\mathrm{p}>0.05$.

\section{Discussion}

The findings of this study reveal significant effects of self-efficacy and the adversity quotient on students' achievement in mathematics. This means that self-efficacy and the adversity quotient were considered to be predictive of performance outcomes in mathematics. The higher students' self-efficacy and adversity quotient, the better their academic achievement in mathematics. These findings supported Bandura's social cognitive theory (SCT) and its main construct of self-efficacy, which is defined as one's belief in one's ability to succeed in specific situations or accomplish a task (Luszczynska, \& Schwarzer, 2005) and can contribute to the better performance and practice of work motivation.

The findings of the present study are also consistent with the results of the previous studies (Saeid \& Eslaminejad, 2017; Kitsantas, Cheema, \& Ware, 2011; Pajares \& Miller, 1994), showing that self-confidence is critical for 
students to succeed in learning mathematics. Confident students are more motivated and more likely to learn mathematics and to be successful in classes. The findings of this study also show that the adversity quotient has a significant influence on mathematics achievement. These results support three other studies performed by Amalia (2011), Wiswayana (2007), and Fadhila (2010), who found a significant relationship between the adversity quotient and students' academic achievement.

However, when the analysis was conducted for each dimension of the independent variable, only one dimension of self-efficacy was found to be significant: self-confidence in one's ability. Furthermore, only two dimensions of the adversity quotient were found to be significant: control as well as origin and ownership. The dimension of self-confidence in one's ability contributed $10 \%$ to students' mathematics achievement. The results are consistent with research conducted by Conger, as cited in Apollo (2005), who found that students who have faith in their abilities will have a strong learning performance. The dimension of control in this study contributed $2.1 \%$. This supports the previous findings of Stoltz (2000) that control has a considerable influence on students' academic achievement. The same results were found in a study by Utami and Hawadi (2006), who found that the control variable contributes significantly to students' achievement in mathematics and natural sciences. Thus, it can be understood that self-control can be linked to self-confidence because students who have self-control in the learning process will have self-confidence in their ability to succeed.

The findings of this study further indicate that there were no significant gender differences related to the effect of self-efficacy and the adversity quotient on students' mathematics achievement. These findings differ from a previous study by Awan, Noureen, and Naz (2012), who investigated the relationships among achievement motivation, self-concept and achievement in English and mathematics at the secondary level in Malaysia. Their findings revealed significant gender differences in favor of girls. A study by Else-Quest, Hyde, and Linn (2010) in the United States also showed that a gender gap in mathematics achievement persists in some nations but not in others. Similarly, a study by Benbow and Stanley (1980) found a substantial sex difference in mathematical reasoning ability in favor of boys in a study of 9927 intellectually gifted junior high school students in the United States. One possible explanation for why gender difference was not found in the presented study could be because Indonesian students have different norms, culture, traditions, and expectations than students in other countries. Therefore, the way Indonesian students learn mathematics in school and home as well as the way they interact with each other could be different, so for them, gender differences are not significant factor that affects their academic achievement in mathematics.

\section{Conclusion and Recommendations}

This study has shown that self-efficacy and the adversity quotient are two determining factors for students' mathematics achievement. About $13 \%$ of students' achievement in mathematics was determined by self-efficacy and the adversity quotient. However, there were no significant effects of gender on students' achievement in mathematics. Therefore, an implication of the study is that we must investigate how to improve students' self-efficacy and adversity quotient in mathematics. The results of the present study may be of interest to other developing countries, especially those in Southeast Asia that share similar concerns with Indonesia regarding students' mathematics achievement.

Since the present study investigated only two internal factors, further research is needed to investigate the other factors affecting students' mathematics achievement. These factors might include both internal factors, such as self-regulated learning, self-concept, and resilience, and external factors, such as parenting styles, teaching strategies, and homework. The findings of the study indicated that there were significant effects of self-efficacy and the adversity quotient on students' achievement in mathematics. Thus, it is necessary for school counselors to enhance and improve these two factors by providing counseling services to students. Subject teachers and class teachers are also suggested to help students with high support needs in learning mathematics.

Finally, our study and its findings indicate that there were many differences but also similarities when analyzing the factors affecting students' mathematics achievement in schools. Therefore, it is expected that the results of the present study may be of interest to other developing countries, especially those in Southeast Asia region that share similar concerns with Indonesia regarding students' mathematics achievement.

\section{Limitations of the Study}

Despite the findings of this study, the researchers are also fully aware of the fact that this study has some limitations. First, the independent variable investigated in the present study is limited to two internal factors, self-efficacy and the adversity quotient, which means that this study does not take into account the importance of external factors. Second, the sample size of the present study is limited to 140 students in Grade IX at MTs Pembangunan UIN Jakarta. This might limit the generalizability of the findings of the present study to other 
situations.

\section{Acknowledgements}

We wish to express our heartfelt gratitude to the Center for Research and Community Services and Faculty of Psychology, Universitas Islam Negeri (UIN) Syarif Hidayatullah Jakarta, Indonesia for their support for this project and for providing relevant guidance. Our sincerest thanks also go to the reviewers for their invaluable comments and scrutiny, which assisted this study tremendously.

\section{References}

Abdelkarim, R., \& Abuiyada, R. (2016). The Effect of Peer Teaching on Mathematics Academic Achievement of the Undergraduate Students in Oman. Journal of International Education Studies, 9(5), 124-132. http://dx.doi.org/10.5539/ies.v6n11p1

Amalia, K. R. (2011). Pengaruh self regulated learning dan adversity quotient terhadap prestasi belajar siswa SMP terbuka (Unpublished Bachelor Thesis). Faculty of Psychology, Universitas Islam Negeri Syarif Hidayatullah, Jakarta.

Apollo. (2005). Hubungan antara kepercayaan diri dengan prestasi belajar siswa/Relationship between selfconfidence and students' academic performance. Jurnal Psikologi Tabularasa, 3(1), 46-63.

Awan, R. U. N., Noureen. G., \& Naz, A. (2012). A Study of Relationship between Achievement Motivation, Self Concept and Achievement in English and Mathematics at Secondary. Journal of International Education Studies, 4(3), 72-79. http://dx.doi.org/10.5539/ies.v4n3p72

Benbow, C. P., \& Stanley, J. C. (1980). Sex differences in mathematical ability: Fact or artifact? Science, 210(4475), 1262-1264. http://dx.doi.org/10.1126/science.7434028

Center for Educational Assessment or Pusat Penilaian Pendidikan/Puspendik. (2016). Report on Analysis of National Examination Year 2016. Jakarta: Ministry of Education and Culture Republic of Indonesia.

Douglas, G, A. \& Kristin, C., J. (2000). Improving Student Achievement in Mathematics, Part 1: Research Findings. ERIC Digest. ED463952.

Else-Quest, N. M., Hyde, J. S., \& Linn, M. C. (2010). Cross-national patterns of gender differences in mathematics: a meta-analysis. Psychological Bulletin, 136(1), 103-127. http://dx.doi.org/10.1037/a0018053

Fadhila, A. N. (2010). Hubungan antara adversity quotient dengan prestasi belajar siswa SMAIT Nurul Fikri Depok dan SMA 106 Jakarta (Unpublished Bachelor Thesis). Faculty of Psychology, Universitas Islam Negeri Syarif Hidayatullah, Jakarta.

Ghufron, \& Risnawati. (2010). Teori-teori psikologi (Theories of psychology). Jogjakarta: Ar-ruzz Media.

Gonzales, P. (2009). Highlights from TIMSS 2007: Mathematics and science achievement of U.S. Fourth and eighth-grade students in an international context. NCES 2009-001 Revised U.S. Department Of Education: Washington, DC, USA.

Hamid, M., H., S., Shahrill, M., Matzin, R., Mahalle, S., \& Mundia, L. (2013). Barriers to Mathematics Achievement in Brunei Secondary School Students: Insights into the Roles of Mathematics Anxiety, Self-Esteem, Proactive Coping, and Test Stress. Journal of International Education Studies, 6(11).1-14. http://dx.doi.org/:10.5539/ies.v6n11p1

Hernández, M. (2014). The Relationship between Mathematics Achievement and Socio- Economic Status. Journal of Education, Policy Planning and administration, 4(1), 75-93.

Ismail, N.A. \& Awang, H. (2009). Mathematics Achievement among Malaysian Students: What Can They Learn from Singapore? Journal of International Education Studies, 2(1), 8-17. $\mathrm{http}: / / \mathrm{dx}$. doi.org/10.5539/ies.v2n1p8

James, A. O., \& Folorunso, A. M. (2012). Effect of Feedback and Remediation on Students' Achievement in Junior Secondary School Mathematics. Journal of International Education Studies, 5(5), 153-162. http://dx.doi.org/10.5539/ies.v5n5p153

Kitsantas, A., Cheema, J., \& Ware, H. W. (2011) Mathematics Achievement: The Role of Homework and

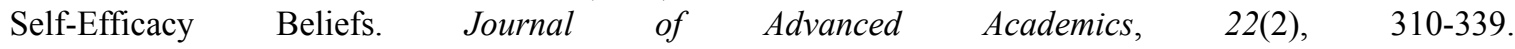
http://dx.doi.org/10.1177/1932202X1102200206

Kupari, P., \& Nissinen, K. (2013). Background factors behind mathematics achievement in Finnish education context: Explanatory models based on TIMSS 1999 and TIMSS 2011 data. In IEA CONFERENCE 2013, 
Proceedings. Retrieved from http://www.iea.nl/fileadmin/user_upload/IRC/IRC_2013/Papers/IRC-2013_ Kupari_Nissinen.pdf

Luszczynska, A., \& Schwarzer, R. (2005). Social cognitive theory. In M. Conner, \& P. Norman (Eds.), Predicting health behaviour (2nd ed. rev., pp. 127-169). Buckingham, England: Open University Press.

Pajares, F., \& Miller, M. D. (1994). Role of self-efficacy and self-concept beliefs in mathematical problem solving: A path analysis. Journal of educational psychology, 86(2), 193. http://dx.doi.org/10.1037/0022-0663.86.2.193

Program for International Student Assessment/PISA. (2013). PISA 2012 Results in Focus. Retrieved from https://www.oecd.org

Program for International Student Assessment/PISA. (2016). PISA 2015 Results in Focus. Retrieved from https://www.oecd.org

Retnaningsih. (1998). Konsep diri dan prestasi belajar siswa/Self concept and student academic performance. Jurnal Penelitian Psikologi, 1(3), 36-41.

Saeid, N., \& Eslaminejad, T. (2017). Relationship between Student's Self-Directed-Learning Readiness and Academic Self-Efficacy and Achievement Motivation in Students. Journal of International Education Studies, 10(1), 225-232. http://dx.doi.org/10.5539/ies.v10n1p225

Shofiah, V. (2002). Hubungan kepercayaan diri dan motivasi berprestasi dengan prestasi belajar pada mahasiswa Universitas Islam Batik Surakarta tahun akademik 2000/2001 (Unpublished master's thesis). Faculty of Psychology, Gadjah Mada University, Jogjakarta.

Singh, P. K., \& Shukla, R. P. (2015). Relationship between Career Maturity and Self-Efficacy among Male and Female Senior Secondary Students. MIER Journal of Educational Studies, Trends \& Practices, 5(2), 164-179.

Stoltz, G. P. (2000). Adversity Quotient: Mengubah hambatan menjadi peluang. Alih Bahasa: Hermaya, T. Jakarta: PT Grasindo.

Suri, G. (2000). Peranan intelegensi, dukungan orang tua, dan belajar matematika menggunakan metode sempoa terhadap prestasi belajar matematika siswa Sekolah Dasar kelas IV-VI (Unpublished bachelor thesis). Faculty of Psychology, University of Indonesia, Depok.

Utami, M., \& Hawadi. (2006). Kontribusi adversity quotient terhadap prestasi belajar SMU program percepatan belajar di Jakarta. Jurnal Penelitian Psikologi, 2(11), 137-148.

Wiswayana, N. P. (2007). Pengaruh model belajar berbasis masalah dan adversity quotient siswa terhadap prestasi belajar matematika dan konsep diri siswa SMA Negeri 4 Singaraja. Jurnal Ilmiah Pendidikan dan Pembelajaran, JIPP, Desember 2007, 774-787.

\section{Copyrights}

Copyright for this article is retained by the author(s), with first publication rights granted to the journal.

This is an open-access article distributed under the terms and conditions of the Creative Commons Attribution license (http://creativecommons.org/licenses/by/4.0/). 